\title{
Incorporation of root-derived carbon into soil microarthropods varies between cropping systems
}

\author{
Zhipeng $\mathrm{Li}^{1}{ }^{1}(1)$ Nicole Scheunemann ${ }^{1,2} \cdot$ Anton M. Potapov ${ }^{1,3} \cdot$ Lingling Shi ${ }^{4,5} \cdot$ Johanna Pausch $^{6} \cdot$ Stefan Scheu $^{1,7}$. \\ Melanie M. Pollierer ${ }^{1}$
}

Received: 19 December 2019 / Revised: 20 March 2020 / Accepted: 12 April 2020 / Published online: 7 May 2020

(C) The Author(s) 2020

\begin{abstract}
As the dynamics and magnitude of rhizodeposition vary considerably among cropping systems, we investigated effects of cropping system on the incorporation of root-derived carbon $(\mathrm{C})$ into Collembola, a dominant taxon of soil microarthropods. In the field, we used ${ }^{13} \mathrm{CO}_{2}$ to pulse label a crop monoculture (oilseed rape, Brassica napus L.), a mixed-grass community (dominated by Lolium perenne L. mixed with clover Trifolium repens L.), and a tree plantation (willow, Salix schwerinii E.L. Wolf and Salix viminalis L.). During 28 days, the incorporation of ${ }^{13} \mathrm{C}$ was traced in nine species of Collembola including epedaphic (surface-dwelling), hemiedaphic (litter-dwelling), and euedaphic (soil-dwelling) functional groups. Incorporation of ${ }^{13} \mathrm{C}$ into Collembola reached a plateau before day 3 after the labeling in grass and willow, but increased up to day 14 in rape. While euedaphic Collembola incorporated less root-derived $\mathrm{C}$ than epedaphic and hemiedaphic Collembola in rape and willow, the incorporation of ${ }^{13} \mathrm{C}$ was similar among functional groups in grass. Differential incorporation of ${ }^{13} \mathrm{C}$ in euedaphic species points to niche differentiation within the same functional group. Our findings highlight that cropping system not only affects the flux of root $\mathrm{C}$ into soil mesofauna, being slower in rape than in grass and willow, but also the utilization of root-derived resources by functional groups and species of Collembola. The results indicate that pronounced differences in belowground $\mathrm{C}$ inputs between cropping systems affect microbivores as basal species and thereby soil food webs and their functioning and services.
\end{abstract}

Keywords ${ }^{13} \mathrm{C}$ labeling $\cdot$ Collembola $\cdot$ Functional group $\cdot$ Grass $\cdot$ Rape $\cdot$ Willow

\section{Introduction}

Considerable amounts (10-20\%) of C are released by plants into soil as rhizodeposition shortly after fixation (Kuzyakov and Domanski 2000; Dennis et al. 2010). This root-derived C

Electronic supplementary material The online version of this article (https://doi.org/10.1007/s00374-020-01467-8) contains supplementary material, which is available to authorized users.

\section{Zhipeng Li}

lizhipengucas@gmail.com

1 J.F. Blumenbach Institute of Zoology and Anthropology, University of Göttingen, Untere Karspüle 2, 37073 Göttingen, Germany

2 Section Mesofauna, Department of Soil Zoology, Senckenberg Museum of Natural History Görlitz, Am Museum 1, 02826 Görlitz, Germany

3 A.N. Severtsov Institute of Ecology and Evolution, Russian Academy of Sciences, Leninsky Prospect 33, 119071 Moscow, Russia comprises mainly low-molecular-weight compounds, such as glucose, organic acids, and amino acids, which are preferentially taken up by soil organisms (Dennis et al. 2010). Collembola play a major role in soil food webs, contributing to $\mathrm{C}$ transport at the litter-soil interface (Chamberlain et al.
4 Key Laboratory for Plant Diversity and Biogeography of East Asia, Kunming Institute of Botany, Chinese Academy of Sciences, Heilongtan, Kunming 650201, Yunnan, China

5 Department of Agricultural Soil Science, University of Göttingen, 37707 Göttingen, Germany

6 Department of Agroecology, University of Bayreuth, Universitätsstraße 30, 95440 Bayreuth, Germany

Centre of Biodiversity and Sustainable Land Use, University of Göttingen, Von-Siebold-Straße 8, 37075 Göttingen, Germany 
2006), and channeling $C$ and nutrients from multiple resources to predators at higher trophic levels (Oelbermann et al. 2008; Liu et al. 2016). Stable isotope studies showed that Collembola quickly incorporate recently fixed $\mathrm{C}$ via multiple pathways, including plants, bacteria, saprotrophic/ mycorrhizal fungi, and other soil animals (Pollierer et al. 2012; Ferlian et al. 2015; Scheunemann et al. 2016). However, how cropping systems affect the incorporation of root-derived $\mathrm{C}$ into Collembola is little understood.

Incorporation of root $\mathrm{C}$ into the soil food web depends on the allocation of recently fixed $\mathrm{C}$ by plants to roots and rhizodeposits, and this varies with the strategies of plants to exploit nutrients from soil (Kuzyakov and Domanski 2000; Pausch and Kuzyakov 2018). Crops allocate large amounts of fixed $\mathrm{C}$ to aboveground biomass since they typically are selected to maximize the growth of fruits and grains, leading to low flux of fixed $\mathrm{C}$ to belowground plant compartments (Pausch and Kuzyakov 2018). The application of fertilizers also results in low allocation of assimilates to belowground plant compartments due to decreasing plant investment in nutrient absorption (Phillips et al. 2011). By contrast, grass and trees are likely to allocate more fixed $\mathrm{C}$ below the ground as compared to annual crops, as they invest more into the exploitation of nutrients from soil (Grayston et al. 1997; Pausch and Kuzyakov 2018). In addition, rhizosphere microorganisms differ between cropping systems; for example, mycorrhizal fungi effectively distribute recently fixed plant $\mathrm{C}$ to the soil microbial community and may facilitate the uptake of rootderived $\mathrm{C}$ by microbivores.

Different functional groups of Collembola living in different soil depths potentially differ in the utilization of rootderived C (Potapov et al. 2016a). Due to closer association with roots, euedaphic Collembola inhabiting the mineral soil presumably incorporate more root-derived $\mathrm{C}$ than hemiedaphic and epedaphic Collembola, which preferentially colonize organic layers or the soil surface (Scheunemann et al. 2010; Potapov et al. 2016a). However, incorporation of rootderived $\mathrm{C}$ by different functional groups may differ between cropping systems due to trophic plasticity of Collembola species (Ruess et al. 2005; Endlweber et al. 2009; Scheunemann et al. 2015; Eerpina et al. 2017).

To explore variations in the incorporation of plant-derived $\mathrm{C}$ into Collembola, we pulse labeled three cropping systems with ${ }^{13} \mathrm{CO}_{2}$ and traced the incorporation of root $\mathrm{C}$ into nine Collembola species of different functional groups. The cropping systems included a herbaceous crop monoculture (oilseed rape, Brassica napus L.), a mixed-grass community (grassland dominated by Lolium perenne L. mixed with clover Trifolium repens L.), and a tree plantation (willow, Salix schwerinii E.L. Wolf and Salix viminalis L.). We tested the following hypotheses: (i) The incorporation of $\operatorname{root} \mathrm{C}$ from grass and willow into Collembola is faster than that from rape, due to higher belowground $\mathrm{C}$ allocation in grasses and trees than in annual crops, and/or to application of fertilizer and lack of mycorrhizal symbiosis in rape. (ii) Euedaphic Collembola incorporate more root-derived $\mathrm{C}$ than epedaphic and hemiedaphic Collembola due to closer association of euedaphic Collembola with plant roots. (iii) Incorporation of root-derived $\mathrm{C}$ differs between species within functional groups and the differences will vary among cropping systems.

\section{Materials and methods}

\section{Site description}

The study sites were located in Reiffenhausen, south of Göttingen in central Germany ( $51^{\circ} 39^{\prime} 83^{\prime \prime} \mathrm{N} / 9^{\circ} 98^{\prime} 75^{\prime \prime} \mathrm{E}$; 325 m.a.s.l.). Average annual temperature is $9.1^{\circ} \mathrm{C}$, and the mean annual precipitation is $635 \mathrm{~mm}$ (Richter et al. 2015). The soil at the study sites is sedimentary deposits of Middle and Upper Triassic Sandstone material, partly mixed with claystone material and covered by loess sediments. The texture of soil varies from loamy sand in the eastern part to silty loam in the western part (Hartmann and Lamersdorf 2015; Tariq et al. 2018). The experiment was established on former cropland in March 2011. The preceding crop grown on the experimental sites was winter barley (Hordeum vulgare L.).

\section{Experimental design}

Fields planted with three cropping systems comprising rape (oilseed rape, Brassica napus L.), grass (dominated by Lolium perenne L., mixed with clover Trifolium repens L.), and tree (willow, Salix schwerinii E.L. Wolf and Salix viminalis L.) were established (Ehret et al. 2015; Tariq et al. 2018). The willow and grass sites were established in March 2011. In September 2015, part of the grass sites was transformed into rape fields. The rape site represents cropland of high land-use intensity including fertilizer application, annual harvest, and crop rotation. The grass site represents low input grassland without fertilizer application but with three cuts per year (Ehret et al. 2015). The willow site was planted as low input short-term forest rotation system with a rotation cycle of 3 years without application of fertilizer. The willow trees were about 3 years old and $4 \mathrm{~m}$ height in our experiment. The willow site and grass site were arranged as an agroforest with rows of willow stripes and grassland strips in between (three willow stripes, each $7.5 \mathrm{~m}$ wide and $75 \mathrm{~m}$ long, and three grassland stripes, each $9 \mathrm{~m}$ wide and $75 \mathrm{~m}$ long). The rape site was next to one of the outer willow stripes ( $18 \mathrm{~m}$ wide and $75 \mathrm{~m}$ long).

In each of cropping systems, five labeling chambers were installed. In the rape field, the chambers were randomly positioned at a distance of 5 to $10 \mathrm{~m}$ from each other in May 2017. For labeling willow, one stripe adjacent to the rape field was 
selected and the chambers were spaced at least by $10 \mathrm{~m}$ and installed in July 2017. In the grass stripes, grass plots were established as blocks differing in, e.g., application of fertilizer (Ehret et al. 2015). Since the size of individual blocks $(9.0 \times$ $6.5 \mathrm{~m}$ ) was too small to install five chambers, we installed the chambers in two blocks with the same treatment (no fertilizer addition) in August 2017, two chambers in block one which was next to the selected willow stripe, and three chambers in block two spaced by $50 \mathrm{~m}$ to block one. The chambers consisted of stainless steel frames of $1 \times 1 \mathrm{~m}$ which were inserted into the soil to a depth of $10 \mathrm{~cm}$ and of a plastic frame on top (height $1 \mathrm{~m}$ for rape and grass, $2 \mathrm{~m}$ for willow) that was covered with translucent LDPE (low-density polyethylene) foil. Plants were labeled by the addition of $\mathrm{HCl}$ to $20 \mathrm{~g}$ $\mathrm{Ca}^{13} \mathrm{CO}_{3}$ in a plastic beaker. In willow, upper branches were bent to fit the height of the chamber. In addition, understory plants were removed and the soil surface was covered with black plastic foil before labeling to exclude ${ }^{13} \mathrm{C}$ incorporation by herbaceous plants and algae. The produced ${ }^{13} \mathrm{CO}_{2}$ was circulated in the chambers by a fan for $6 \mathrm{~h}$. After labeling, the foil and plastic frame were removed, while the steel frame remained in the soil to prevent migration of animals between labeled and unlabeled areas (Scheunemann et al. 2016). The fact that ${ }^{13} \mathrm{C}$ enrichment did not decrease in most Collembola species throughout the experiment indicated that this procedure was effective.

Sites of different cropping systems were close to each other and were established on one former field. Therefore, our study sites may not be perfectly independent of each other. However, establishing the study sites on similar background provided a number of advantages for testing our hypothesis. First, small spatial distances between sites allowed us to sample the same Collembola species across all study sites, a crucial precondition to study variations in nutrition of Collembola species between cropping systems. In addition, it restricted effects of confounding variables, such as differences in soil type, on the flux of root $\mathrm{C}$ into soil food webs. Finally, the distance between labeling chambers was at least $5 \mathrm{~m}$ to minimize spatial dependence.

\section{Sampling}

Soil samples were taken $3,7,14$, and 28 days after labeling to analyze the dynamics of ${ }^{13} \mathrm{C}$ incorporation into Collembola. Additionally, unlabeled samples were taken at adjacent plots and served as control for analyzing ${ }^{13} \mathrm{C}$ and ${ }^{15} \mathrm{~N}$ natural abundance in each cropping system. In each chamber, one soil sample was taken at each sampling date using a stainless steel soil corer (diameter $20 \mathrm{~cm}$, depth $10 \mathrm{~cm}$ ). Soil arthropods were extracted by heat (Kempson et al. 1963) and stored in $70 \%$ ethanol at $-20^{\circ} \mathrm{C}$. Collembola were identified to species level using a Zeiss microscope (Hopkin 2007). The nine abundant Collembola species across all sites were selected for stable isotope analysis: epedaphic species including Isotoma viridis (Bourlet), Lepidocyrtus cyaneus (Tullberg), Lepidocyrtus paradoxus (Uzel), and Orchesella villosa (Geoffroy); hemiedaphic species including Folsomia quadrioculata (Tullberg), Parisotoma notabilis (Schäffer), and Pseudosinella alba (Packard); and euedaphic species including Protaphorura armata (Tullberg) and Stenaphorura denisi (Bagnall). The classification of functional groups was based on Potapov et al. (2016b).

\section{Stable isotope analysis}

Approximately $50 \mu \mathrm{g}$ of dry weight of each Collembola species (from 1 to 30 individuals) was weighed into tin capsules, which were analyzed for ${ }^{13} \mathrm{C} /{ }^{12} \mathrm{C}$ with a coupled system of an elemental analyzer (NA1110, CE-Instruments, Rodano, Milano, Italy) and an isotope ratio mass spectrometer (Delta Plus, Finnigan MAT, Bremen, Germany) located at the Centre for Stable Isotope Research and Analysis, Göttingen, Germany. V-PDB was used as a standard for ${ }^{13} \mathrm{C}$. Acetanilide was used for internal calibration. Isotope natural abundance was expressed using the delta notation with $\delta^{13} \mathrm{C}=\left[\left(R_{\text {sample }}-R_{\text {standard }}\right) / R_{\text {standard }}\right] \times 1000 . R_{\text {sample }}$ and $R_{\text {standard }}$ refer to the ${ }^{13} \mathrm{C} /{ }^{12} \mathrm{C}$ in samples and standard, respectively. Incorporation of ${ }^{13} \mathrm{C}$ into Collembola was calculated for each species as shift in the isotope signature between labeled and control sample as ${ }^{13} \mathrm{C}$ enrichment $\Delta{ }^{13} \mathrm{C}$

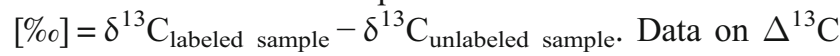
of shoot/leave and root (visible fine roots shorted by hand), soil dissolved organic C, and soil PLFAs were provided by Lingling Shi (unpubl. data).

\section{Statistical analysis}

$\Delta^{13} \mathrm{C}$ values of Collembola were compared between sampling days, Collembola species, and functional groups using linear mixed effects models for each cropping system. In the first model, species and sampling days were set as fixed effects. As different spatial scales investigated were nested in a hierarchical structure ("soil core" nested within "chamber," "chamber" nested within "cropping system"), stable isotope data of Collembola from the same soil core and from the same chamber were not independent. We accounted for this by setting "chamber" and "soil core" nested within "chamber" as random effects. In the second model, $\Delta{ }^{13} \mathrm{C}$ values of Collembola were compared between functional groups of Collembola and days with "species," "chamber," and "soil core" nested within "chamber" as random effects. In the third model, we averaged $\Delta^{13} \mathrm{C}$ values from different sampling days for each chamber and species and used the natural abundance $\delta^{13} \mathrm{C}$ values as fixed effects; random effects were "chamber" and "species." Since chambers in grass were distributed in two blocks, we also used "block" as random effect in the model of grass. 
Because the epedaphic species L. paradoxus had considerably lower $\Delta^{13} \mathrm{C}$ values in rape and distinct dynamics compared to the other three epedaphic species, it was excluded in the second and third models. Similar to the third model, we also analyzed the relationship between average $\Delta^{13} \mathrm{C}$ values of Collembola species and their body length and abundance in rape, grass, and willow.

For each model, heteroscedasticity was inspected by plotting the residuals against the predicted values and normality was checked by Quantile-Quantile plots. $\Delta^{13} \mathrm{C}$ values were transformed (logarithmic or Box-cox transformations) if homogeneity of variance and normality were not satisfied. All statistical analyses were conducted using R 3.4.2 (R Core team 2016), packages lme4 (Bates et al. 2015), and lmerTest (Kuznetsova et al. 2017). Plots were drawn in R using the package ggplot2 (Wickham 2016).

\section{Results}

\section{Incorporation of ${ }^{13} \mathrm{C}$ into Collembola in different cropping systems}

Three days after labeling, the ${ }^{13} \mathrm{C}$ enrichment of shoots of rape, grass, and willow was $399.6 \pm 91.7,826.6 \pm 209.6$, and $355.1 \pm 176.5 \%$, respectively (Table S1). High ${ }^{13} \mathrm{C}$ concentration in plant tissue early after labeling allowed us to reliably trace the incorporation of recently fixed $\mathrm{C}$ into Collembola.

The incorporation of ${ }^{13} \mathrm{C}$ into Collembola differed markedly between sampling days in rape, but stayed relatively constant in grass and willow (Table 1). Except for L. paradoxus and $S$. denisi, ${ }^{13} \mathrm{C}$ incorporation into Collembola in rape increased gradually after labeling, reached a plateau at day 7 or 14 and then stayed constant until day 28 (Fig. 1). In grass, ${ }^{13} \mathrm{C}$ incorporation was already high at day 3 and stayed relatively constant in most species except for L. paradoxus and $O$. villosa, which reached their peaks at days 7 and 14, respectively (Fig. 2). In willow, ${ }^{13} \mathrm{C}$ incorporation (overall mean enrichment $13.6 \pm 19.9 \%$ ) was generally lower than that in grass $(187.3 \pm 216 \%$ ) and rape $(80.99 \pm 74.8 \%$ ) and stayed more constant than that in rape after labeling. Incorporation of

${ }^{13} \mathrm{C}$ in willow was lowest in $S$. denisi and P. armata (Fig. 3).

\section{Incorporation of ${ }^{13} \mathrm{C}$ into Collembola functional groups}

Incorporation of ${ }^{13} \mathrm{C}$ differed significantly between Collembola functional groups in willow and rape, with epedaphic and hemiedaphic Collembola being more enriched than euedaphic Collembola (Table 2, Fig. 4). In rape, differences between functional groups depended on sampling day, being more pronounced after day 7 . By contrast, incorporation of ${ }^{13} \mathrm{C}$ did not differ significantly between functional groups in grass (Table 2, Fig. 4).

\section{Species-specific differences in the incorporation of ${ }^{13} \mathrm{C}$}

The random effects of species in the model of functional groups were significant in all cropping systems $(p<0.001)$; that is, the incorporation of ${ }^{13} \mathrm{C}$ into Collembola significantly differed between species within the same functional group (Table 1). In the euedaphic group, $\Delta{ }^{13} \mathrm{C}$ values in $P$. armata were significantly higher than those in $S$. denisi in each of the cropping systems (Fig. 5). Species-specific differences in the other functional groups depended on cropping system. For instance, $P$. alba was more enriched than the other hemiedaphic species in grass and willow, but not in rape. $\Delta^{13} \mathrm{C}$ values in L. paradoxus were lower than those in the other epedaphic species in rape, but similar in grass and willow.

Table 1 Linear mixed effects model of type III error for the effect of species, sampling day, and their interaction on the incorporation of ${ }^{13} \mathrm{C}$ into Collembola in different cropping systems (rape, grass, and willow)

\begin{tabular}{llllllll}
\hline Cropping system & Factor & Sum of square & Mean of square & df1 & df2 & $F$ value & $P$ value \\
\hline Rape & Species & 22.09 & 2.76 & 8 & 97.22 & 66.68 & $<0.001$ \\
& Day & 9.83 & 3.28 & 3 & 13.07 & 79.15 & $<0.001$ \\
& Species $\times$ day & 4.54 & 0.19 & 24 & 96.97 & 4.57 & $<0.001$ \\
Grass & Species & 9.47 & 1.18 & 8 & 79.81 & 23.70 & $<0.001$ \\
& Day & 0.05 & 0.05 & 3 & 14.75 & 0.33 & 0.804 \\
& Species $\times$ day & 3.83 & 0.16 & 24 & 80.25 & 3.19 & $<0.001$ \\
Willow & Species & 7.02 & 0.88 & 8 & 73.85 & 18.33 & $<0.001$ \\
& Day & 0.47 & 0.16 & 3 & 15.13 & 3.25 & 0.052 \\
& Species $\times$ day & 1.19 & 0.05 & 24 & 74.93 & 1.03 \\
\hline
\end{tabular}

$d f 1$ numerator degree of freedom, $d f 2$ denominator degree of freedom

Significant effects are in italics 


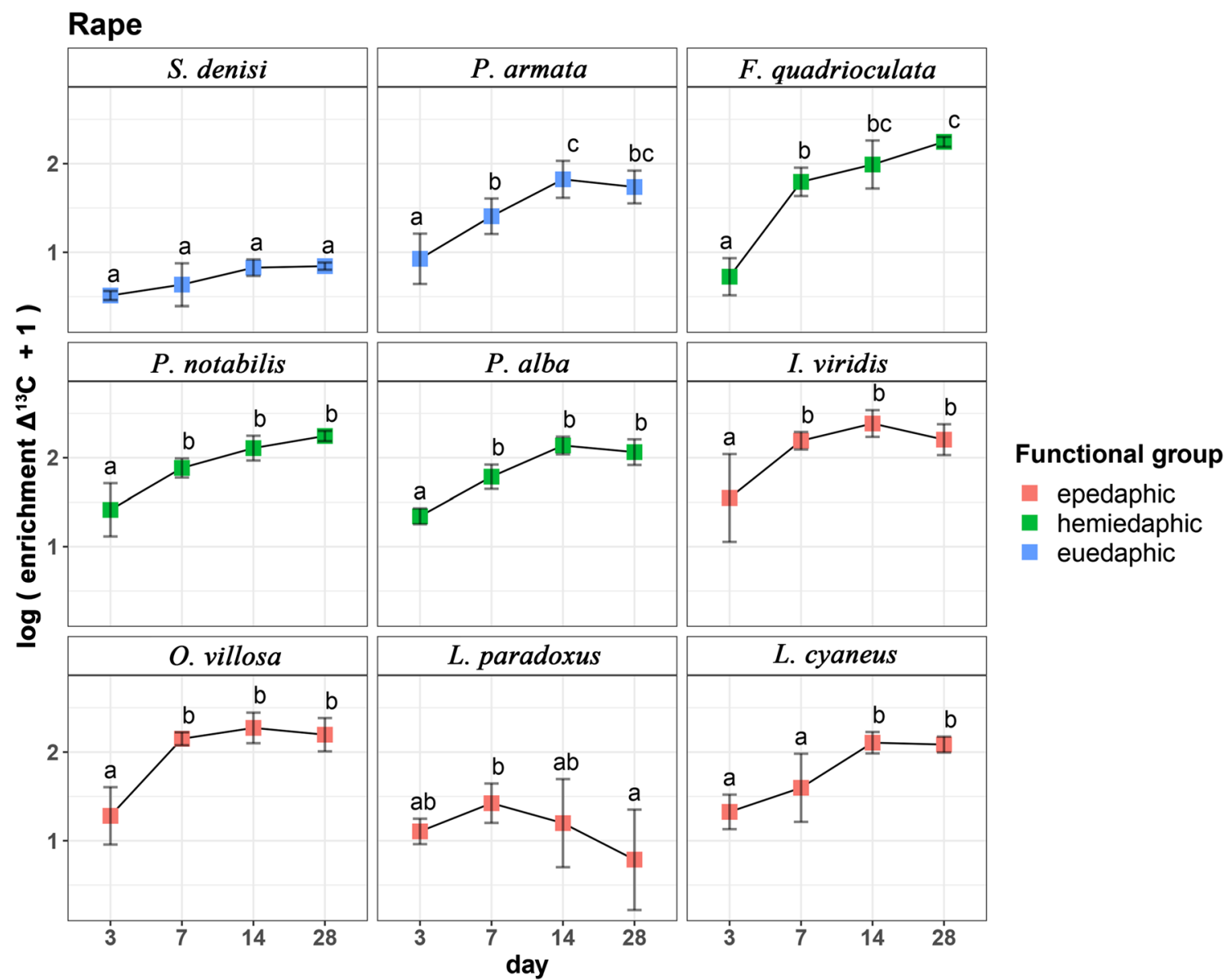

Fig. 1 Incorporation of ${ }^{13} \mathrm{C}$ into Collembola species (Stenaphorura denisi, Protaphorura armata, Folsomia quadrioculata, Parisotoma notabilis, Pseudosinella alba, Isotoma viridis, Orchesella villosa, Lepidocyrtus paradoxus, Lepidocyrtus cyaneus) 3, 7, 14, and 28 days

$\Delta{ }^{13} \mathrm{C}$ values of Collembola species negatively correlated with their natural abundance values of ${ }^{13} \mathrm{C}\left(\delta^{13} \mathrm{C}\right)$ in rape, grass, and willow; however, the correlation was not significant in the latter (Table S2, Fig. 6). In none of the cropping systems, $\Delta{ }^{13} \mathrm{C}$ values of Collembola species were significantly correlated with their abundance nor their body length (data not shown).

\section{Discussion}

\section{Influence of cropping system on the utilization of root C}

Collembola rapidly incorporated the labeled $\mathrm{C}$ in each of the cropping systems (rape, grass, and willow), indicating that soil food webs under these cropping systems are fueled by recently fixed $\mathrm{C}$. This is in line with previous studies showing that soil invertebrates incorporated recently fixed $\mathrm{C}$ in arable systems, grasslands, temperate, and boreal forests, most likely via rhizodeposits and associated microorganisms (Pollierer et al. after labeling in rape; means $\pm \mathrm{SD}$. Values of different sampling dates within a species with the same letters are not significantly different $(p<0.05$; Tukey's HSD test)

2007; Högberg et al. 2010; Seeber et al. 2012; Eissfeller et al. 2013; Goncharov et al. 2016; Scheunemann et al. 2016). Our study for the first time showed that incorporation dynamics of recently fixed $\mathrm{C}$ and its distribution among different functional groups and species of Collembola are markedly different among cropping systems.

Supporting our first hypothesis, the incorporation of ${ }^{13} \mathrm{C}$ into Collembola reached a peak on days $0-3$ in grass and willow but at day 7 or 14 in rape (Figs. 1, 2, and 3), indicating slower root $\mathrm{C}$ flux into Collembola in rape than in grass and willow. In other labeling experiments, incorporation of ${ }^{13} \mathrm{C}$ into Collembola also increased with time in cropland (Pausch et al. 2016; Scheunemann et al. 2016), while staying relatively constant or without clear trend in grassland (Ostle et al. 2007) and forest (Högberg et al. 2010; Fujii et al. 2016). This may reflect the lower $\mathrm{C}$ allocation to roots in rape compared to grass and willow (Kuzyakov and Domanski 2000; Pausch and Kuzyakov 2018), presumably because crop species are selected to maximize the growth of harvested plant compartments (Pausch and Kuzyakov 2018). By contrast, perennial grasses translocate more $\mathrm{C}$ belowground (30-50\%) 


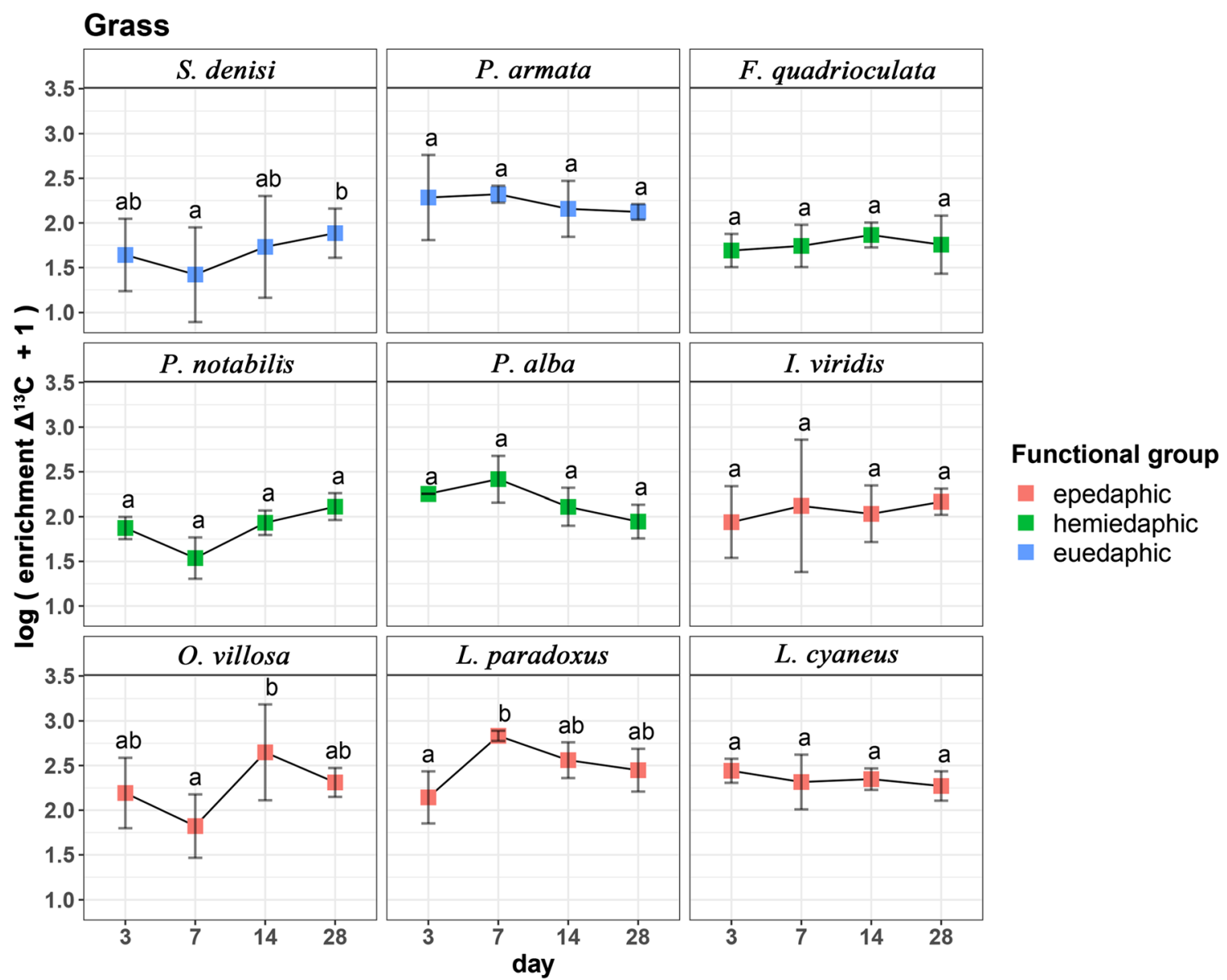

Fig. 2 Incorporation of ${ }^{13} \mathrm{C}$ into Collembola species 3, 7, 14, and 28 days after labeling in grass; means $\pm \mathrm{SD}$. Values of different sampling dates within a species with the same letters are not significantly different ( $p<0.05$; Tukey's HSD test). For abbreviations, see Fig. 1

than crops (20-30\%) since they rely on belowground $\mathrm{C}$ reserves for regrowth in spring and after grazing or mowing (Pausch and Kuzyakov 2018). Application of fertilizer likely further decreased belowground $\mathrm{C}$ allocation in rape. Typically, fertilization with $\mathrm{N}$ reduces the allocation of $\mathrm{C}$ to roots and the root-to-shoot biomass ratio (Hermans et al. 2006), which directly or indirectly results in lower $\mathrm{C}$ supply to soil microorganisms and animals (Ai et al. 2015; Denef et al. 2009; Högberg et al. 2010). Supporting this assumption, the ${ }^{13} \mathrm{C}$ enrichment of dissolved organic $\mathrm{C}$ in soil increased gradually and peaked at day 14 in rape, while it peaked at day 3 in grass and willow (Table S3), reflecting lower exudation and/or lower microbial assimilation efficiency of root exudates in rape than in grass and willow. Thus, the transfer efficiency of rootderived $\mathrm{C}$ to microorganisms and to microbivorous arthropods presumably was lower in rape than in grass and willow.

Association between plants and soil microorganisms differs between cropping systems, and this is likely to be another important factor affecting the flux of root $\mathrm{C}$ into rhizosphere animal consumers such as Collembola. Grasses and willows form symbiotic associations with mycorrhizal fungi (Sumorok and Kiedrzynska 2007; Baum et al. 2009; Nicolson and
Johnston 2009), and this might be associated with higher root exudation compared to non-mycorrhizal plants such as oilseed rape (Okubo et al. 2016). High allocation of plant $\mathrm{C}$ to mycorrhizal fungi and root exudates assimilated by saprotrophic rhizosphere microorganisms in grass and willow (Denef et al. 2007; Kušliene et al. 2014) is likely to result in fast incorporation of root $\mathrm{C}$ into rhizosphere consumers. In addition, mycorrhizal and saprotrophic fungal mycelia efficiently transfer root $\mathrm{C}$ from the rhizosphere to root-free bulk soil (Butler et al. 2003; Kušliene et al. 2014) facilitating the capture of root $C$ by Collembola. By contrast, incorporation of root $\mathrm{C}$ into animal consumers may be hampered by the absence of mycorrhizal associations in rape (Kühn et al. 2019). This likely results in a more uneven distribution of root $\mathrm{C}$ in bulk soil, thus reducing the incorporation of root-derived $\mathrm{C}$ into Collembola.

The ${ }^{13} \mathrm{C}$ incorporation into Collembola species was remarkably lower in willow than in grass and rape. Potentially, low enrichment in willow was due to high amounts of unlabeled $\mathrm{C}$ in the phloem that diluted the signal of ${ }^{13} \mathrm{C}$, leading to lower $\Delta^{13} \mathrm{C}$ values in Collembola even when incorporating similar amounts of root $\mathrm{C}$ as in grass and rape. Supporting this assumption, the ${ }^{13} \mathrm{C}$ enrichment of roots (Table S1) and of the 
Willow
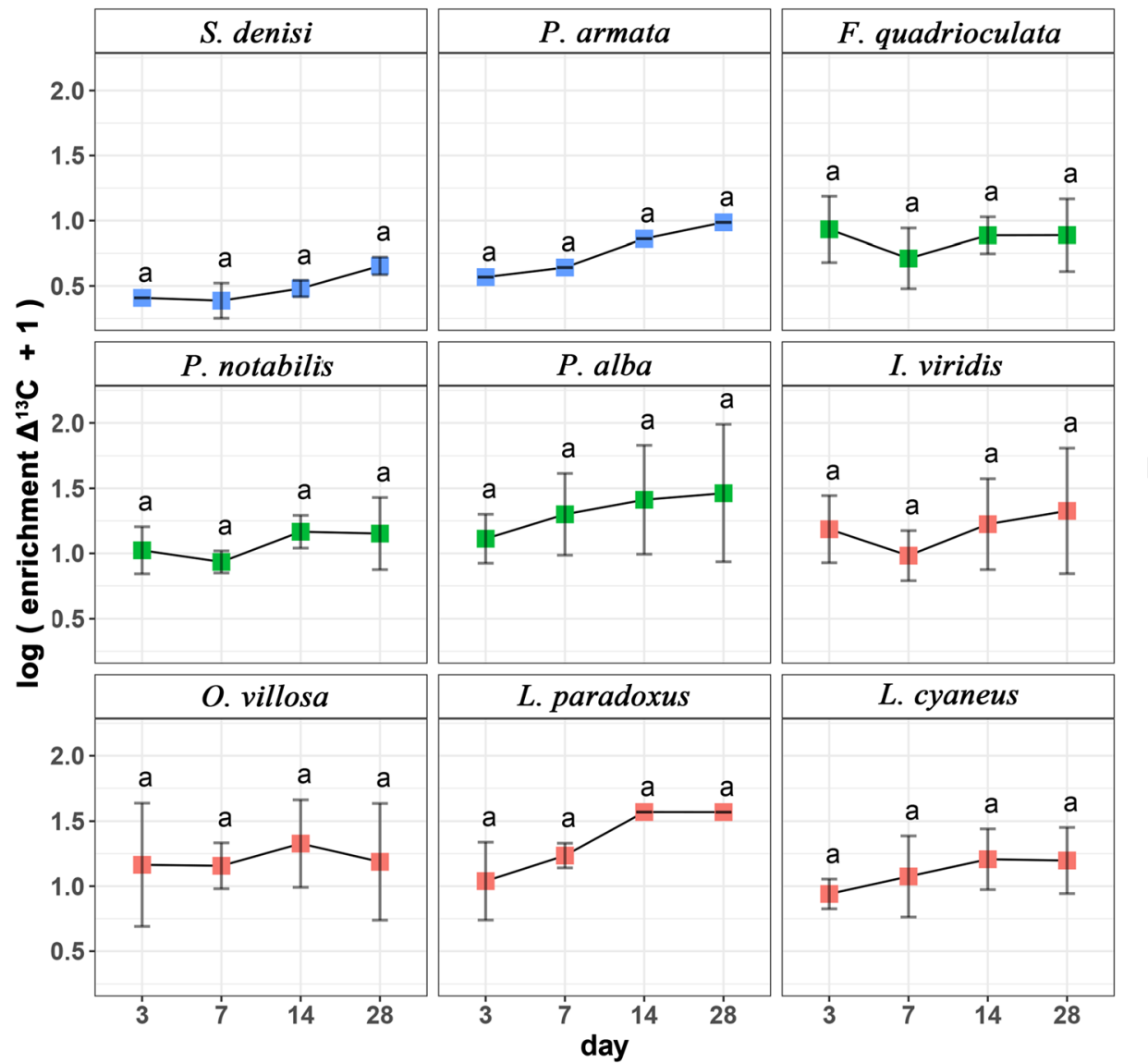

\section{Functional group}

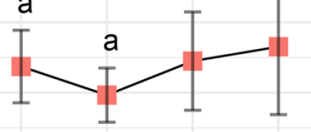

epedaphic

- hemiedaphic

euedaphic

Fig. 3 Incorporation of ${ }^{13} \mathrm{C}$ into Collembola species 3, 7, 14, and 28 days after labeling in willow; means $\pm \mathrm{SD}$. Values of different sampling dates within a species with the same letters are not significantly different $(p<0.05$; Tukey's HSD test). For abbreviations, see Fig. 1

biomarker PLFA 18:2w6,9 in soil were also lower in willow than in grass and rape (Lingling Shi, unpubl. data). Although the PLFA 18:2w6,9 originates from both roots and fungi, its close correlation with other fungal biomarkers (Högberg 2006; Pausch et al. 2016) and the fact that only sieved soil was analyzed in the present study suggest that it predominantly reflects fungal tissue. Besides dilution effects, ${ }^{13} \mathrm{C}$ loss via respiration of aboveground parts or low belowground allocation of recent photosynthate $\mathrm{C}$ may also have contributed to the low ${ }^{13} \mathrm{C}$ incorporation into Collembola in willow.

Table 2 Linear mixed effects model table of type III error for the effect of functional group, sampling day, and their interaction on the incorporation of

${ }^{13} \mathrm{C}$ into Collembola in different cropping systems (rape, grass, and willow)

\begin{tabular}{|c|c|c|c|c|c|c|c|}
\hline Cropping system & Factor & Sum of square & Mean of square & df1 & $\mathrm{df} 2$ & $F$ value & $P$ value \\
\hline \multirow[t]{3}{*}{ Rape } & fg & 0.64 & 0.32 & 2 & 5.01 & 6.60 & 0.039 \\
\hline & Day & 13.58 & 4.53 & 3 & 14.05 & 94.06 & $<0.001$ \\
\hline & fg $\times$ day & 0.68 & 0.11 & 6 & 105.42 & 2.34 & 0.036 \\
\hline \multirow[t]{3}{*}{ Grass } & $\mathrm{fg}$ & 0.28 & 0.14 & 2 & 5.85 & 1.87 & 0.235 \\
\hline & Day & 0.13 & 0.04 & 3 & 15.79 & 0.59 & 0.634 \\
\hline & fg $\times$ day & 0.42 & 0.07 & 6 & 98.76 & 0.93 & 0.481 \\
\hline \multirow[t]{3}{*}{ Willow } & $\mathrm{fg}$ & 1.38 & 0.66 & 2 & 5.90 & 6.62 & 0.031 \\
\hline & Day & 1.21 & 0.40 & 3 & 19.58 & 4.01 & 0.022 \\
\hline & $\mathrm{fg} \times$ day & 0.77 & 0.13 & 6 & 96.91 & 1.27 & 0.276 \\
\hline
\end{tabular}

$d f 1$ numerator degree of freedom, $d f 2$ denominator degree of freedom, $f g$ functional group

Significant effects are in italics 

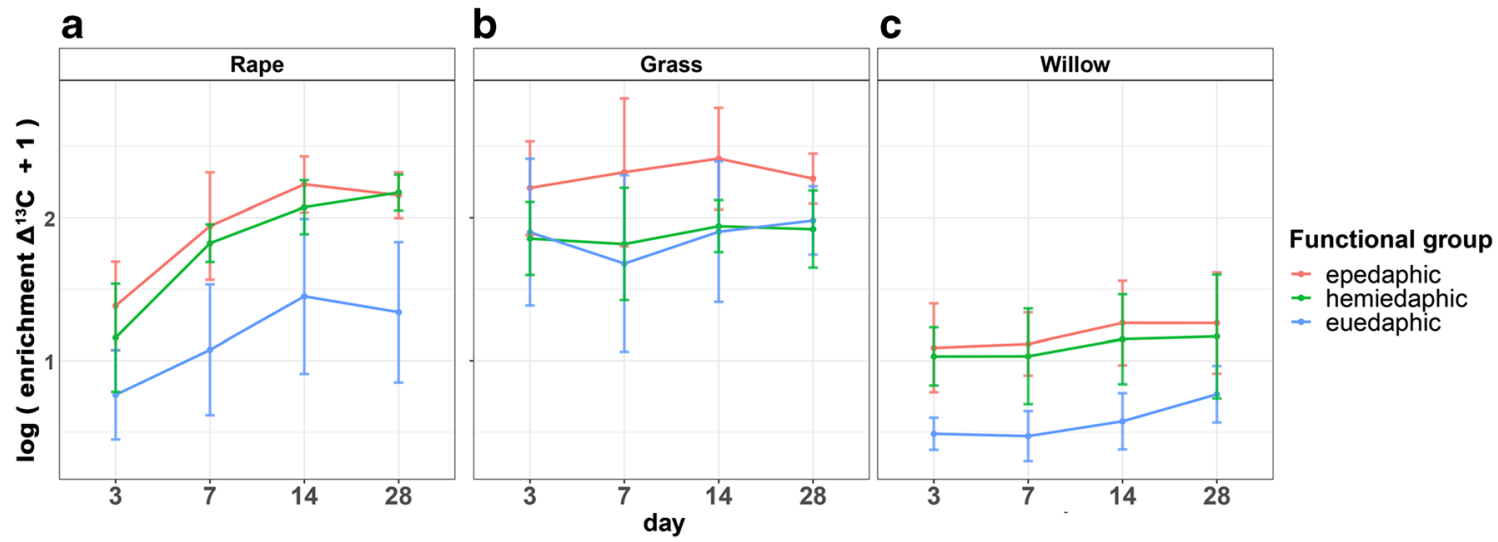

Fig. 4 Incorporation of ${ }^{13} \mathrm{C}$ into Collembola functional groups 3, 7, 14, and 28 days after labeling in fields planted with a rape, $\mathbf{b}$ grass, and $\mathbf{c}$ willow; means \pm SD

Unlike the sites of grass and willow, which were established directly from crop fields, the rape site was established from part of the grass site. Differences in preceding vegetation may have influenced the incorporation of rootderived $\mathrm{C}$ into Collembola due to differentially affecting soil properties and microbial communities. However, legacy effects of the preceding vegetation presumably were minor compared to effects of the present plant types/species and soil management. For instance, Detheridge et al. (2016) showed that the fungal community of cereal fields with different preceding crop species converged already 1 year after establishment. Similarly, Crotty et al. (2016) found that the legacy effect of preceding crop species on the diversity and abundance of soil fauna diminished in the second cropping season during crop rotation, and the abundance of Collembola did not vary any more with the previous crop species.

In the present study, we could not capture variation in belowground $\mathrm{C}$ allocation as influenced by growth period. As our study was conducted during the late growth period of oilseed rape, the rapid growth of flowers and seeds likely diminished the flux of $\mathrm{C}$ to roots and into the soil food web, whereas belowground $\mathrm{C}$ allocation and incorporation presumably is higher in rape at early growth stages (Pausch and Kuzyakov 2018). In grasses, the variation in C allocation with growth stage is relatively minor as compared to annual crops (Pausch and Kuzyakov 2018), whereas the belowground C input from trees potentially is higher in the late than in the early growth period (Mordacq et al. 1986; Kagawa et al. 2006; Högberg et al. 2010). As patterns of ${ }^{13} \mathrm{C}$ incorporation into Collembola potentially differ between growth periods, in particular in rape and willow, further research on seasonal variation in belowground $\mathrm{C}$ inputs in different cropping systems is needed.

\section{Incorporation of root C into Collembola functional groups}

Functional groups of Collembola reflect the habitat they live in, such as litter, humus, and mineral soil (Faber 1991; Ponge 2000; Rusek 2007), which allows to infer distribution of root-

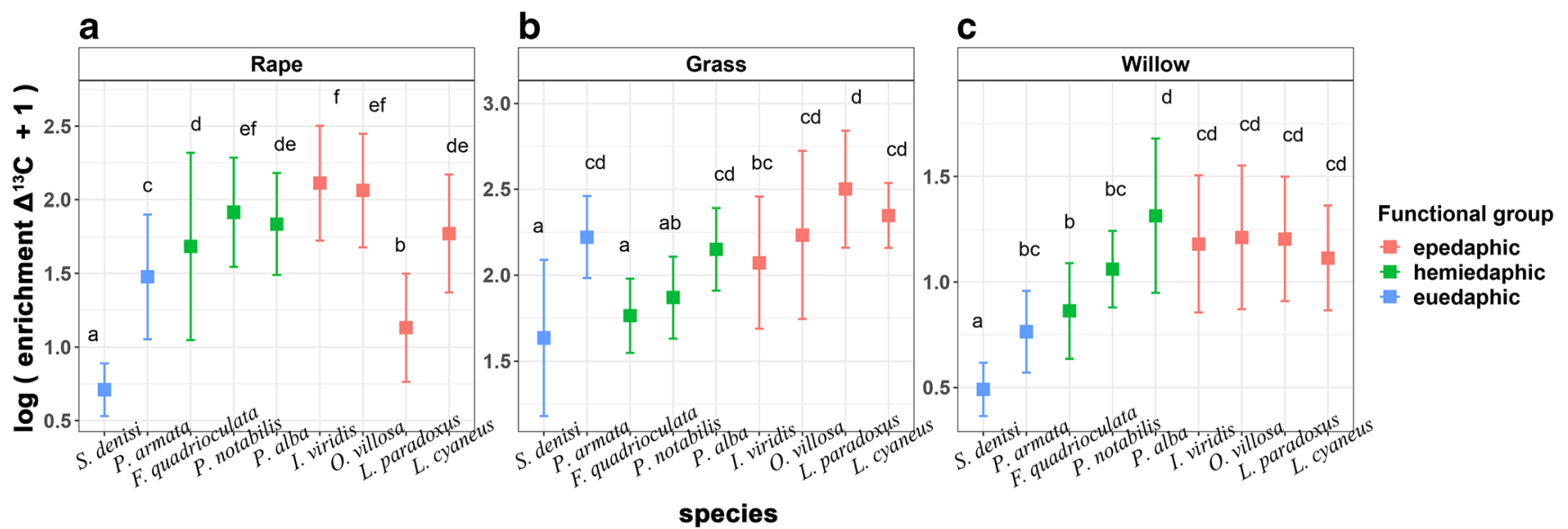

Fig. 5 Incorporation of ${ }^{13} \mathrm{C}$ into Collembola species in fields planted with a rape, $\mathbf{b}$ grass, and $\mathbf{c}$ willow; means $\pm \mathrm{SD}$. All sampling dates are bulked together. Values of different species within a cropping system with the same letters are not significantly different ( $p<0.05$; Tukey's HSD test). For abbreviations, see Fig. 1 


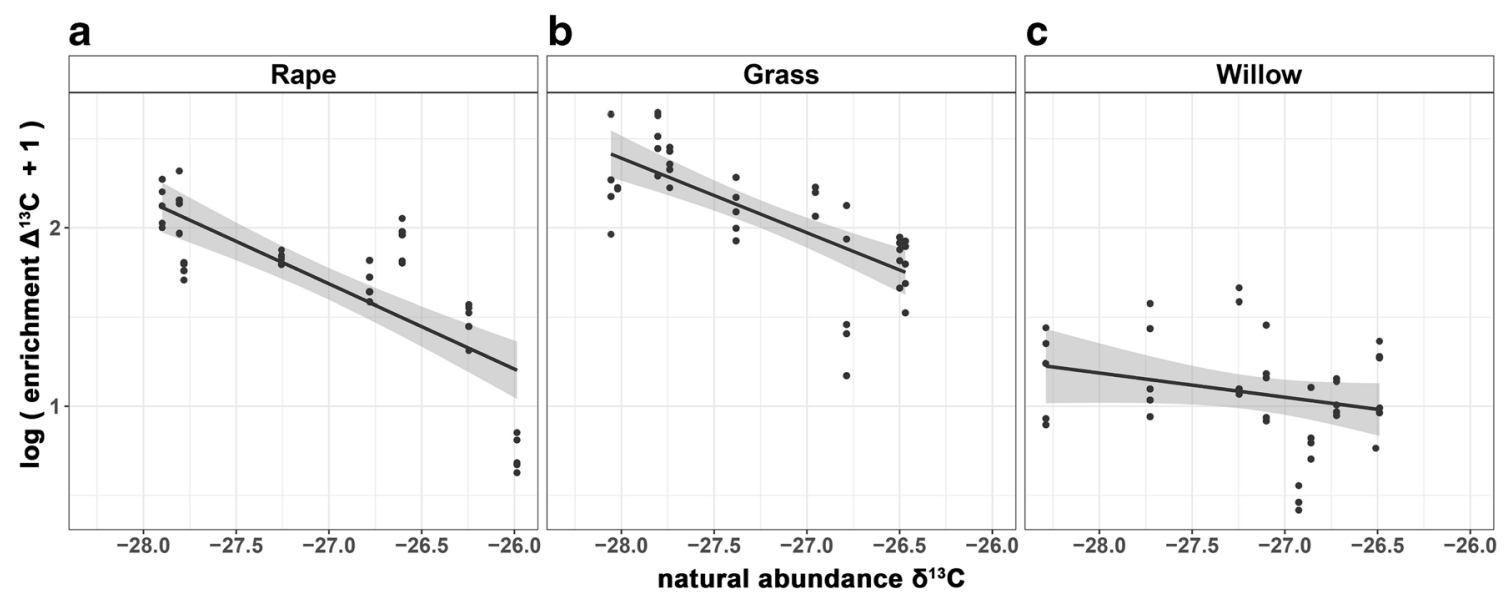

Fig. 6 Correlation between the incorporation of ${ }^{13} \mathrm{C}\left(\Delta^{13} \mathrm{C}\right)$ and the natural abundance of ${ }^{13} \mathrm{C}\left(\delta^{13} \mathrm{C}\right)$ of the same Collembola species in fields planted with a rape, $\mathbf{b}$ grass, and $\mathbf{c}$ willow; data are means per species and chamber

derived $\mathrm{C}$ in soil food webs at different soil depths (Potapov et al. 2016b). In contrast to our second hypothesis, hemiedaphic and epedaphic Collembola incorporated more ${ }^{13} \mathrm{C}$ than euedaphic Collembola in rape and willow (Fig. 4), indicating that soil-dwelling species have limited access to recently fixed $\mathrm{C}$ in these cropping systems. This contradicts previous findings in forests where hemiedaphic Collembola were not strongly labeled (Potapov et al. 2016a; Fujii et al. 2016), possibly because they relied on litter as the major $C$ source in these systems. By contrast, our studies were conducted in arable soil with relatively few litter resources; therefore, hemiedaphic Collembola may shift from litter-derived to root-derived resources. Similar to the results of Scheunemann et al. (2015), the hemiedaphic species $P$. alba incorporated more root-derived $\mathrm{C}$ than the euedaphic species $P$. armata.

The relatively low incorporation of root-derived resources into euedaphic species in rape and willow suggests that they more heavily rely on old $\mathrm{C}$ sources, i.e., soil organic matter and litter, than hemi- and epedaphic species in these cropping systems. Supporting this conclusion, Ponge (2000) found certain euedaphic species to preferentially consume humus rather than root tissue or fungal hyphae. Further, old soil $\mathrm{C}$ accounted for more than $50 \%$ of the body $\mathrm{C}$ of Collembola in maize fields even after prolonged growth of maize (Albers et al. 2006; Scheunemann et al. 2010). This is supported by the relatively high natural $\delta^{15} \mathrm{~N}$ and $\delta^{13} \mathrm{C}$ values of euedaphic Collembola in rape and willow (Table S4), which correspond to the enriched $\delta^{15} \mathrm{~N}$ and $\delta^{13} \mathrm{C}$ values of soil organic matter relative to plant material (Hyodo et al. 2010; Potapov et al. 2019). However, high $\delta^{15} \mathrm{~N}$ values in Collembola may also reflect trophic fractionation due to occupying higher trophic positions within the food web (Chahartaghi et al. 2005).

While the incorporation of root-derived $\mathrm{C}$ differed between functional groups in rape and willow, there was no significant difference between functional groups in grass (Fig, 4). This was mainly due to higher incorporation of root-derived $\mathrm{C}$ into euedaphic species in grassland as compared to rape and willow. Roots of grass may be more palatable than those of rape and willow. This may especially be true for $P$. armata, since its natural abundance $\delta^{13} \mathrm{C}$ values decreased from comparatively high values in rape and willow to low values in grass (Table S4), indicating a more direct trophic relationship to grass roots, presumably via feeding on roots, arbuscular mycorrhizal fungi, or root-feeding nematodes. Previous studies also found euedaphic Collembola species to shift their food preference from root $\mathrm{C}$ to soil organic $\mathrm{C}$ depending on resource availability (Gillet and Ponge 2003; Endlweber et al. 2009; Eerpina et al. 2017). In addition, high belowground $C$ allocation in grass may promote its utilization by different functional groups of Collembola as well as their microbial prey.

Previous studies suggest that epedaphic species potentially have a high preference for aboveground resources such as microalgae, lichens, and organic matter deposited by plants, including pollen and honeydew from aphids (Scheunemann et al. 2010; Potapov et al. 2016a). However, the temporal variation in $\Delta^{13} \mathrm{C}$ values of epedaphic and hemiedaphic species in individual cropping systems was synchronous with that of euedaphic species; since euedaphic species are unlikely to be linked to aboveground resources, the main source of their recently fixed $\mathrm{C}$ is likely to be root-derived. Although photoautotrophic microorganisms might be an important resource for Collembola in upper litter layers or extreme habitats such as rock surface (Potapov et al. 2018), their importance in presence of plant roots remains unknown. Further research separating different channels of recently fixed $\mathrm{C}$ to epedaphic Collembola is required.

\section{Species-specific differences in the incorporation of $\operatorname{root} C$}

Functional group could only partially explain the variation in the incorporation of ${ }^{13} \mathrm{C}$ into Collembola species; 
species within the same functional group also differed in the incorporation of ${ }^{13} \mathrm{C}$ supporting our third hypothesis. Notably, the variation was most pronounced in euedaphic species, with $P$. armata incorporating considerably more root-derived C than $S$. denisi (Fig. 5). In contrast to variations within epedaphic and hemiedaphic groups, this difference persisted in each of the studied cropping systems, indicating remarkable niche differentiation between euedaphic species.

Strong niche differentiation in euedaphic Collembola has also been observed by Potapov et al. (2016a), who found higher dependence on root-derived resources in $P$. armata than in Isotomiella minor, and by Fujii et al. (2016), who found incorporation of root-derived C into Onychiurus flavescens, but not into I. minor. While Protaphorura and Onychiurus belong to the family Onychiuridae, Isotomiella and Stenaphorura belong to families Isotomidae and Tullbergiidae, respectively, characterized by more slender bodies allowing to access smaller soil pores. Thus, the niche differentiation in euedaphic Collembola may be explained partly by morphological differences within functional groups (Potapov et al. 2016b).

More pronounced niche differentiation in euedaphic Collembola potentially points to higher demand for resource partitioning in the mineral soil. The relatively stable environment in mineral soil may facilitate resource exploitation and thereby competition, promoting the differential utilization of root-associated and litter/humus-associated resources among euedaphic species. By contrast, resources in surface soil presumably varied considerably between cropping systems and this likely contributed to the variable uptake of ${ }^{13} \mathrm{C}$ of species of the same functional group in epedaphic and hemiedaphic Collembola. For instance, ${ }^{13} \mathrm{C}$ enrichment in L. paradoxus was lower than that in the other epedaphic species in rape, but similar in grass and willow.

Collembola species with low incorporation of ${ }^{13} \mathrm{C}$ presumably rely less on root-derived $\mathrm{C}$, but more on other unlabeled resources such as soil organic matter. Supporting this assumption, we found the incorporation of ${ }^{13} \mathrm{C}$ into Collembola species $\left(\Delta^{13} \mathrm{C}\right.$ values) to be negatively correlated with bulk tissue ${ }^{13} \mathrm{C}$ natural abundance of Collembola $\left(\delta^{13} \mathrm{C}\right.$ values $)$ in rape and grass (Fig. 6). This is in line with previous studies indicating that low $\delta^{13} \mathrm{C}$ values reflect preferential incorporation of recently fixed plant $\mathrm{C}$; by contrast, high $\delta^{13} \mathrm{C}$ values indicate high incorporation of $\mathrm{C}$ originating from soil organic matter and associated microorganisms (Potapov et al. 2016b, 2019). Interestingly, L. paradoxus in rape had low natural $\delta^{13} \mathrm{C}$ values, but also low incorporation of ${ }^{13} \mathrm{C}$, contrasting other epedaphic species (Fig. 5, Table S4). In addition, ${ }^{13} \mathrm{C}$ enrichment of $L$. paradoxus declined after it peaked at day 7 . This suggests that, unlike the other epedaphic species, L. paradoxus incorporated recently fixed $\mathrm{C}$ from other photoautotrophs than plants, presumably algae or cyanobacteria.
Body size may be another factor affecting the incorporation of ${ }^{13} \mathrm{C}$ into Collembola species, since smaller species with higher mass-specific metabolic rates (Brown and Sibly 2006) may also have a higher rate of ${ }^{13} \mathrm{C}$ incorporation than larger species (Larsen et al. 2009). However, there was no significant correlation between body size and the incorporation of ${ }^{13} \mathrm{C}$ into Collembola species, suggesting that dietary differentiation may play a more important role in governing incorporation of root-derived $\mathrm{C}$ than body size. Although the present study cannot provide details on the exact mechanisms responsible for the differential incorporation of root-derived $\mathrm{C}$ into Collembola species, e.g., by feeding on different microorganisms, our results suggest that the differential use of basal resources may be an important mechanism favoring local coexistence of Collembola species.

\section{Conclusions}

Results of the present study demonstrate that the flux of root-derived $\mathrm{C}$ into soil microbivores, and thus to higher trophic levels of soil food webs, strongly varies between cropping systems. Cropping system not only affected the flux of root $\mathrm{C}$ into Collembola, with slower fluxes in rape than in grass and willow, but also the utilization of rootderived resources vs. litter/soil organic matter-derived resources by Collembola functional groups and species. Thereby, our findings suggest that the role of rootderived $\mathrm{C}$ as major resource fueling soil food webs varies markedly with cropping system, potentially due to differences in plant species/plant type and application of fertilizer. Future studies using novel techniques, such as compound-specific fatty acid, amino acid, and molecular gut content analysis, will allow deeper insight into the relative contributions of fungi and bacteria in channeling recently fixed $\mathrm{C}$ from roots into soil food webs of arable fields with different cropping systems and fertilizer regimes.

Acknowledgements We gratefully acknowledge the China Scholarship Council (CSC) (201604910550) for supporting Zhipeng Li. Melanie M. Pollierer has been funded by the Deutsche Forschungsgemeinschaft (DFG) (MA 7145/1-1). Thanks to Reinhard Langel at the Kompetenzzentrum Stabile Isotope (KOSI), University of Göttingen, for stable isotope measurements, and to Sarah Zieger for advice in linear mixed effects models and stable isotope measurement.

Authors' contributions Stefan Scheu, Johanna Pausch, Nicole Scheunemann, and Lingling Shi designed the experiment. Zhipeng Li, Nicole Scheunemann, and Lingling Shi conducted the experiment. Zhipeng Li, Melanie M. Pollierer and Anton M. Potapov analyzed the data. Zhipeng Li wrote the manuscript, and Melanie M. Pollierer and Stefan Scheu revised it. All authors contributed critically to the drafts and gave final approval for publication. 
Funding information Open Access funding provided by Projekt DEAL.

\section{Compliance with ethical standards}

Conflict of interest The authors declare that they have no conflict of interest.

Open Access This article is licensed under a Creative Commons Attribution 4.0 International License, which permits use, sharing, adaptation, distribution and reproduction in any medium or format, as long as you give appropriate credit to the original author(s) and the source, provide a link to the Creative Commons licence, and indicate if changes were made. The images or other third party material in this article are included in the article's Creative Commons licence, unless indicated otherwise in a credit line to the material. If material is not included in the article's Creative Commons licence and your intended use is not permitted by statutory regulation or exceeds the permitted use, you will need to obtain permission directly from the copyright holder. To view a copy of this licence, visit http://creativecommons.org/licenses/by/4.0/.

\section{References}

Ai C, Liang G, Sun J, Wang X, He P, Zhou W, He X (2015) Reduced dependence of rhizosphere microbiome on plant-derived carbon in 32-year long-term inorganic and organic fertilized soils. Soil Biol Biochem 80:70-78. https://doi.org/10.1016/j.soilbio.2014.09.028

Albers D, Schaefer M, Scheu S (2006) Incorporation of plant carbon into the soil animal food web of an arable system. Ecology 87:235-245. https://doi.org/10.1890/04-1728

Bates D, Maechler M, Bolker B, Walker S (2015) Fitting linear mixedeffects models using lme4. J Stat Softw 67:1-48. https://doi.org/10. 18637/jss.v067.i01

Baum C, Toljander YK, Eckhardt KU, Weih M (2009) The significance of host-fungus combinations in ectomycorrhizal symbioses for the chemical quality of willow foliage. Plant Soil 323:213-224. https:// doi.org/10.1007/s11104-009-9928-x

Brown JH, Sibly RM (2006) Life-history evolution under a production constraint. Proc Natl Acad Sci U S A 103:17595-17599. https://doi. org/10.1073/pnas.0608522103

Butler JL, Williams MA, Bottomley PJ, Myrold DD (2003) Microbial community dynamics associated with rhizosphere carbon flow. Appl Environ Microbiol 69:6793-6800. https://doi.org/10.1128/ AEM.69.11.6793-6800.2003

Chahartaghi M, Langel R, Scheu S, Ruess L (2005) Feeding guilds in Collembola based on nitrogen stable isotope ratios. Soil Biol Biochem 37:1718-1725. https://doi.org/10.1016/J.SOILBIO.2005. 02.006

Chamberlain P, Mcnamara N, Chaplow J, Stott A, Black H (2006) Translocation of surface litter carbon into soil by Collembola. Soil Biol Biochem 38:2655-2664. https://doi.org/10.1016/j.soilbio. 2006.03.021

Crotty FV, Fychan R, Sanderson R, Rhymes JR, Bourdin F, Scullion J, Marley CL (2016) Understanding the legacy effect of previous forage crop and tillage management on soil biology, after conversion to an arable crop rotation. Soil Biol Biochem 103:241-252

Denef K, Bubenheim H, Lenhart K, Vermeulen J, Van Cleemput O, Boeckx P, Müller C (2007) Community shifts and carbon translocation within metabolically-active rhizosphere microorganisms in grasslands under elevated $\mathrm{CO}_{2}$. Biogeosciences 4:769-779. https:// doi.org/10.5194/bg-4-769-2007

Denef K, Roobroeck D, Manimel Wadu MCW, Lootens P, Boeckx P (2009) Microbial community composition and rhizodeposit-carbon assimilation in differently managed temperate grassland soils. Soil Biol Biochem 41:144-153. https://doi.org/10.1016/j.soilbio.2008. 10.008

Dennis PG, Miller AJ, Hirsch PR (2010) Are root exudates more important than other sources of rhizodeposits in structuring rhizosphere bacterial communities? FEMS Microbiol Ecol 72:313-327. https:// doi.org/10.1111/j.1574-6941.2010.00860.x

Detheridge AP, Brand G, Fychan R, Crotty FV, Sanderson R, Griffith GW, Marley CL (2016) The legacy effect of cover crops on soil fungal populations in a cereal rotation. Agric Ecosyst Environ 228: 49-61. https://doi.org/10.1016/j.agee.2016.04.022

Eerpina R, Boiteau G, Lynch DH (2017) Collembola diet switching in the presence of maize roots varies with species. Can J Soil Sci 97:171177. https://doi.org/10.1139/cjss-2016-0057

Ehret M, Bühle L, Graß R, Lamersdorf N, Wachendorf M (2015) Bioenergy provision by an alley cropping system of grassland and shrub willow hybrids: biomass, fuel characteristics and net energy yields. Agrofor Syst 89:365-381. https://doi.org/10.1007/s10457014-9773-7

Eissfeller V, Beyer F, Valtanen K, Hertel D, Maraun M, Polle A, Scheu S (2013) Incorporation of plant carbon and microbial nitrogen into the rhizosphere food web of beech and ash. Soil Biol Biochem 62:76 81. https://doi.org/10.1016/J.SOILBIO.2013.03.002

Endlweber K, Ruess L, Scheu S (2009) Collembola switch diet in presence of plant roots thereby functioning as herbivores. Soil Biol Biochem 41:1151-1154. https://doi.org/10.1016/j.soilbio.2009.02. 022

Faber JH (1991) Functional classification of soil fauna: a new approach. Oikos 62:110. https://doi.org/10.2307/3545458

Ferlian O, Klarner B, Langeneckert AE, Scheu S (2015) Trophic niche differentiation and utilisation of food resources in collembolans based on complementary analyses of fatty acids and stable isotopes. Soil Biol Biochem 82:28-35. https://doi.org/10.1016/J.SOILBIO. 2014.12.012

Fujii S, Mori AS, Kominami Y, Tawa Y, Inagaki Y, Takanashi S, Takeda H (2016) Differential utilization of root-derived carbon among collembolan species. Pedobiologia (Jena) 59:225-227. https://doi.org/ 10.1016/J.PEDOBI.2016.05.001

Gillet S, Ponge JF (2003) Changes in species assemblages and diets of Collembola along a gradient of metal pollution. Appl Soil Ecol 22: 127-138. 10.1016/S0929-1393(02)00134-8

Goncharov AA, Tsurikov SM, Potapov AM, Tiunov AV (2016) Shortterm incorporation of freshly fixed plant carbon into the soil animal food web: field study in a spruce forest. Ecol Res 31:923-933. https://doi.org/10.1007/s11284-016-1402-7

Grayston SJ, Vaughan D, Jones D (1997) Rhizosphere carbon flow in trees, in comparison with annual plants: the importance of root exudation and its impact on microbial activity and nutrient availability. Appl Soil Ecol 5:29-56. https://doi.org/10.1016/S0929-1393(96) 00126-6

Hartmann L, Lamersdorf N (2015) Site conditions, initial growth and nutrient and litter cycling of newly installed short rotation coppice and agroforestry systems. In: Manning DB, Bemmann A, Bredemeier M, Lamersdorf N, Ammer C (eds) Bioenergy from dendromass for the sustainable development of rural areas. WileyVCH Verlag GmbH \& Co. KGaA, Weinheim, pp 121-138

Hermans C, Hammond JP, White PJ, Verbruggen N (2006) How do plants respond to nutrient shortage by biomass allocation? Trends Plant Sci 11:610-617

Högberg MN (2006) Discrepancies between ergosterol and the phospho-

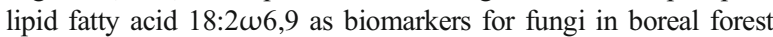
soils. Soil Biol Biochem 38:3431-3435. https://doi.org/10.1016/j. soilbio.2006.06.002

Högberg MN, Briones MJI, Keel SG, Metcalfe DB, Campbell C, Midwood AJ, Thornton B, Hurry V, Linder S, Näsholm T, Högberg P (2010) Quantification of effects of season and nitrogen 
supply on tree below-ground carbon transfer to ectomycorrhizal fungi and other soil organisms in a boreal pine forest. New Phytol 187:485-493. https://doi.org/10.1111/j.1469-8137.2010.03274.x

Hopkin SP (2007) A key to the Collembola (springtails) of Britain and Ireland. FSC Publications

Hyodo F, Kohzu A, Tayasu I (2010) Linking aboveground and belowground food webs through carbon and nitrogen stable isotope analyses. Ecol Res 25:745-756. https://doi.org/10.1007/s11284-0100719-x

Kagawa A, Sugimoto A, Maximov TC (2006) Seasonal course of translocation, storage and remobilization of ${ }^{13} \mathrm{C}$ pulse-labeled photoassimilate in naturally growing Larix gmelinii saplings. New Phytol 171:793-804. https://doi.org/10.1111/j.1469-8137.2006. 01780.x

Kempson D, Lloyd M, Ghelardi R (1963) A new extractor for woodland litter. Pedobiologia 3:1-21

Kühn J, Schweitzer K, Ruess L (2019) Diversity and specificity of lipid patterns in basal soil food web resources. PLoS One 14:e0221102. https://doi.org/10.1371/journal.pone.0221102

Kušliene G, Rasmussen J, Kuzyakov Y, Eriksen J (2014) Medium-term response of microbial community to rhizodeposits of white clover and ryegrass and tracing of active processes induced by ${ }^{13} \mathrm{C}$ and ${ }^{15} \mathrm{~N}$ labelled exudates. Soil Biol Biochem 76:22-33. https://doi.org/10. 1016/j.soilbio.2014.05.003

Kuznetsova A, Brockhoff PB, Christensen RHB (2017) lmerTest package: tests in linear mixed effects models. J Stat Softw 82:1-26. https://doi.org/10.18637/jss.v082.i13

Kuzyakov Y, Domanski G (2000) Carbon input by plants into the soil. Review J Plant Nutr Soil Sci 163:421-431. https://doi.org/10.1002/ 1522-2624(200008)163:4<421::AID-JPLN421>3.0.CO;2-R

Larsen T, Ventura M, Damgaard C, Hobbie E, Krogh PH (2009) Nutrient allocations and metabolism in two collembolans with contrasting reproduction and growth strategies. Funct Ecol 23:745-755. https://doi.org/10.1111/j.1365-2435.2009.01564.x

Liu S, Behm JE, Chen J, Fu S, He X, Hu J, Schaefer D, Gan J, Yang X (2016) Functional redundancy dampens the trophic cascade effect of a web-building spider in a tropical forest floor. Soil Biol Biochem 98:22-29. https://doi.org/10.1016/J.SOILBIO.2016.03.020

Mordacq L, Mousseau M, Deleens E (1986) A ${ }^{13} \mathrm{C}$ method of estimation of carbon allocation to roots in a young chestnut coppice. Plant Cell Environ 9:735-739. https://doi.org/10.1111/j.1365-3040.1986. tb02106.x

Nicolson TH, Johnston C (2009) Mycorrhiza in the Gramineae. Trans Br Mycol Soc 72:261-268. https://doi.org/10.1016/s0007-1536(79) 80041-8

Oelbermann K, Langel R, Scheu S (2008) Utilization of prey from the decomposer system by generalist predators of grassland. Oecologia 155:605-617. https://doi.org/10.1007/s00442-007-0927-4

Okubo A, Matsusaka M, Sugiyama S (2016) Impacts of root symbiotic associations on interspecific variation in sugar exudation rates and rhizosphere microbial communities: a comparison among four plant families. Plant Soil 399:345-356. https://doi.org/10.1007/s11104015-2703-2

Ostle N, Briones MJI, Ineson P, Cole L, Staddon P, Sleep D (2007) Isotopic detection of recent photosynthate carbon flow into grassland rhizosphere fauna. Soil Biol Biochem 39:768-777. https://doi. org/10.1016/j.soilbio.2006.09.025

Pausch J, Kuzyakov Y (2018) Carbon input by roots into the soil: quantification of rhizodeposition from root to ecosystem scale. Glob Chang Biol 24:1-12. https://doi.org/10.1111/gcb.13850

Pausch J, Kramer S, Scharroba A, Scheunemann N, Butenschoen O, Kandeler E, Marhan S, Riederer M, Scheu S, Kuzyakov Y, Ruess L (2016) Small but active - pool size does not matter for carbon incorporation in below-ground food webs. Funct Ecol 30:479489. https://doi.org/10.1111/1365-2435.12512
Phillips RP, Finzi AC, Bernhardt ES (2011) Enhanced root exudation induces microbial feedbacks to $\mathrm{N}$ cycling in a pine forest under long-term $\mathrm{CO}_{2}$ fumigation. Ecol Lett 14:187-194. https://doi.org/ 10.1111/j.1461-0248.2010.01570.x

Pollierer MM, Langel R, Körner C, Maraun M, Scheu S (2007) The underestimated importance of belowground carbon input for forest soil animal food webs. Ecol Lett 10:729-736. https://doi.org/10. 1111/j.1461-0248.2007.01064.x

Pollierer MM, Dyckmans J, Scheu S, Haubert D (2012) Carbon flux through fungi and bacteria into the forest soil animal food web as indicated by compound-specific ${ }^{13} \mathrm{C}$ fatty acid analysis. Funct Ecol 26:978-990. https://doi.org/10.1111/j.1365-2435.2012.02005.x

Ponge JF (2000) Vertical distribution of Collembola (Hexapoda) and their food resources in organic horizons of beech forests. Biol Fertil Soils 32:508-522. https://doi.org/10.1007/s003740000285

Potapov AM, Goncharov AA, Tsurikov SM, Tully T, Tiunov AV (2016a) Assimilation of plant-derived freshly fixed carbon by soil collembolans: not only via roots? Pedobiologia (Jena) 59:189-193. https:// doi.org/10.1016/j.pedobi.2016.07.002

Potapov AM, Semenina EE, Korotkevich AY, Kuznetsova NA, Tiunov AV (2016b) Connecting taxonomy and ecology: trophic niches of collembolans as related to taxonomic identity and life forms. Soil Biol Biochem 101:20-31. https://doi.org/10.1016/j.soilbio.2016.07. 002

Potapov AM, Korotkevich AY, Tiunov AV (2018) Non-vascular plants as a food source for litter-dwelling Collembola: field evidence. Pedobiologia (Jena) 66:11-17. https://doi.org/10.1016/j.pedobi. 2017.12.005

Potapov AM, Tiunov AV, Scheu S (2019) Uncovering trophic positions and food resources of soil animals using bulk natural stable isotope composition. Biol Rev 94:37-59. https://doi.org/10.1111/brv.12434

R Core Team (2016) R: A language and environment for statistical computing. R Foundation for Statistical Computing, Vienna. URL https://www.R-project.org/

Richter F, Döring C, Jansen M, Panferov O, Spank U, Bernhofer C (2015) How to predict hydrological effects of local land use change: how the vegetation parameterisation for short rotation coppices influences model results. Hydrol Earth Syst Sci 19:3457-3474. https:// doi.org/10.5194/hess-19-3457-2015

Ruess L, Schütz K, Haubert D, Häggblom MM, Kandeler E, Scheu S (2005) Application of lipid analysis to understand trophic interactions in soil. Ecology 86:2075-2082. https://doi.org/10.1890/041399

Rusek J (2007) A new classification of Collembola and Protura life forms. Contrib to soil Zool Cent Eur II:109-115

Scheunemann N, Scheu S, Butenschoen O (2010) Incorporation of decade old soil carbon into the soil animal food web of an arable system. Appl Soil Ecol 46:59-63. https://doi.org/10.1016/j.apsoil. 2010.06.014

Scheunemann N, Digel C, Scheu S, Butenschoen O (2015) Roots rather than shoot residues drive soil arthropod communities of arable fields. Oecologia 179:1135-1145. https://doi.org/10.1007/s00442015-3415-2

Scheunemann N, Pausch J, Digel C, Kramer S, Scharroba A, Kuzyakov Y, Kandeler E, Ruess L, Butenschoen O, Scheu S (2016) Incorporation of root $\mathrm{C}$ and fertilizer $\mathrm{N}$ into the food web of an arable field: variations with functional group and energy channel. Food Webs 9:39-45. https://doi.org/10.1016/J.FOOWEB.2016.02. 006

Seeber J, Rief A, Richter A, Traugott M, Bahn M (2012) Droughtinduced reduction in uptake of recently photosynthesized carbon by springtails and mites in alpine grassland. Soil Biol Biochem 55: 37-39. https://doi.org/10.1016/J.SOILBIO.2012.06.009

Sumorok B, Kiedrzynska E (2007) Mycorrhizal status of native willow species in the Pilica River floodplain along the moisture gradient. In: Okruszko T, Maltby E, Szatyłowicz J, Świątek D, Kotowski W (eds) 
Wetlands: monitoring. Modelling and Management. Taylor \& Francis, London, pp 281-286

Tariq A, Gunina A, Lamersdorf N (2018) Initial changes in soil properties and carbon sequestration potential under monocultures and shortrotation alley coppices with poplar and willow after three years of plantation. Sci Total Environ 634:963-973. https://doi.org/10.1016/ J.SCITOTENV.2018.03.391
Wickham H (2016) ggplot2: elegant graphics for data analysis. SpringerVerlag, New York

Publisher's note Springer Nature remains neutral with regard to jurisdictional claims in published maps and institutional affiliations. 